\title{
Quality characteristics and antioxidative activity of fermented milk added with hot water extract of Cordyceps militaris grown upon Tenebrio molitor
}

\author{
Do-Woo Gim ${ }^{1}$, Hui-Yeon Koo ${ }^{2}$, Seon-Gon Kim², Jun-Ki Park ${ }^{1}$, Yu-Jin Kim ${ }^{1}$, \\ Chang-Ki Huh ${ }^{1}$, Yong-Doo Kim ${ }^{1}$, Hyun-Jin Kim ${ }^{2 *}$ \\ ${ }^{1}$ Department of Food Science and Technology, Sunchon National University, Suncheon 57922, Korea \\ ${ }^{2}$ Insects and Sericultural Research Institute, Jeollanamdo Agricultural Research and Extention Services, \\ Jangseong 57214, Korea
}

\section{갈색거저리 유래 밀리타리스 동충하초 열수 추출물을 첨가한 발효유의 품질 특성과 항산화 활성}

\author{
김도우 ${ }^{1} \cdot$ 구희연 $^{2} \cdot$ 김선곤 $^{2} \cdot$ 박준기 $^{1} \cdot{\text { 김 } \text { 유진 }^{1} \cdot \text { 허창기 }^{1} \cdot \text { 김용두 }}^{1} \cdot$ 김현진 $^{2 *}$ \\ ${ }^{1}$ 순천대학교 식품공학과, ${ }^{2}$ 전남농업기술원 곤충잠업연구소
}

\begin{abstract}
This study was carried out to investigate the physicochemical and antioxidant properties of fermented milk with addition of hot water extract of Cordyceps militaris grown upon Tenebrio molitor. The general components of Cordyceps militaris grown upon Tenebrio molitor are moisture $10.85 \%$, crude protein $18.44 \%$, crude fat $2.07 \%$, crude ash 5.46\%. The DPPH radical scavenging activities of different solvents were the highest (74.81 EDA\%) with hot water extract sample. The acidity of fermented milk was high with increasing amount of extracts. The pH of fermented milk reached 4.60-4.66 after $4 \mathrm{~h}$ of fermentation, and the number of lactic acid bacteria was highest (11.70 $\log \mathrm{CFU} / \mathrm{mL})$ with $1 \%$ fermented milk. The moisture content of fermented milk showed no significant difference. In addition, contents of crude protein were not significantly different according to addition amount. Regarding Hunter's color values, $L$ value decreased as the amount of extract increased, whereas a value and $b$ value increased. The content of free amino acid increased with increasing amount of extract. The DPPH free radical scavenging ability and ABTS free radical scavenging ability of fermented milk were significantly different as the addition amount of extract increased. In the sensory evaluation, fermented milk containing $1 \%$ of extract showed the highest preference.
\end{abstract}

Key words : Tenebrio molitor, Cordyceps militaris hot water, fermented milk, physicochemical, antioxidative

\section{서 론}

최근 식량 수급 문제의 대안 중 하나는 곤충을 새로운 단백질 공급원으로 활용 하고자 하는 식용곤충 분야이다.

*Corresponding author. E-mail : hjkim12@korea.kr Phone : 82-61-399-1714, Fax : 82-61-363-6014

Received 14 November 2017; Revised 18 December 2017; Accepted 19 December 2017.

Copyright (c) The Korean Society of Food Preservation. All rights reserved.
현재 갈색거저리는 국외에서는 예전부터 식용으로 많이 이용되고 있었으며, 국내에서도 2016년 농촌진흥청에서 그 영양성과 안전성 평가 결과를 바탕으로 식품의약품안전처 에 식품 원료 등록 신청을 통해 현재는 식품 원료로 인정을 받은 상황이다(1).

갈색 거저리는 곤충 체내에 $44-70 \%$ 의 단백질을 함유하 고 있어 좋은 영양원이며, 지질, 탄수화물, 비타민 함량이 높아서 식품으로써 우수하게 평가되고 있다(2). 또한 거저 리는 필수아미노산 함량이 높으며(3), 이용이 가능한 미래 유망한 식량원으로 가능성이 높다(4). 갈색거저리에 대한 
연구는 형태적 특징, 키틴합성 저해제의 활성평가 및 항진 균 단백질 등의 연구가 진행 되어졌으며(5,6), 최근에 생태 적 특성과 갈색거저리의 영양성분에 대한 연구(7-9) 등이 이루어지고 있다. 또한 거저리의 생화학 성분의 하나인 단 백질분해 소화효소는 고영양소로서 뿐만 아니라 곤충의 생산물을 효과적으로 조절할 수 있는 물질로 많은 연구들이 수행되었다(10). 동충하초는 누에, 벌, 나비, 풍뎅이, 애벌 레, 유충, 번데기 등과 같은 곤충의 호흡기와 소화기로 Cordyceps균이 침입하여 기생자로써 영양분을 섭취하다가 숙주가 죽으면 버섯으로 성장한 것이다(11). 겨울에는 벌레 상태이던 것이 여름이 되면 풀처럼 돋아나 신비한 버섯이 된다하여 동충하초라 부르게 되었으며 전 세계적으로 약 300 여 종이 보고되었고 국내에서도 76종을 채집하여 분리 동정하였다고 보고 되어있다(12). 한방에서는 오래전부터 약재로 사용해 왔으며 중국의 고서 본초종신(本草從新), 본 초강목습유(本草綱目拾遺) 에서는 폐와 신장의 기능을 돕 고, 지혈에도 탁월하며 가래를 삭일 수 있고 그 효능이 인삼 과 같다고 기록되어있다 $(13,14)$. 이 외에도 백혈병, 비염, 기관지염, 아토피, 고혈압, 심장병, 이명과 같은 질병에도 치료율이 높은 것으로 알려지면서(15) 동충하초 분말을 첨 가한 식빵(16), 설기 떡(17), 한방식초(18) 등 많은 식품에 첨가되어 건강기능성 식품으로서 입지를 굳히고 있다. 갈 색거저리 소재를 통해 생산한 갈색거저리 동충하초는 최근 개발된 식품소재로써 다양한 제품 개발 연구가 필요한 상황 이다.

시장경제의 악화와 출산의 저하로 백색 우유 시장은 물 론 유제품 관련 시장이 지속해서 주춤하는 가운데 유제품 소비 시장의 위기감이 고조되어 가고 있다. 발효유의 국내 소비시장 규모는 2014년 9,518억 원에서 2016년 9,538억 원으로 최근 3 년간 약 $0.2 \%$ 로 약간의 증가세를 보였다. 하지만 이러한 상황을 낙관해서는 안되며 시장 확대를 위한 다양한 발효유 제품들이 개발되어 경쟁력을 갖춰야 한다 (19). 발효유는 젖소나 산양, 말과 같은 포유동물의 젖을 유산균이나 효모로 발효시킨 것으로 과거 동지중해(지중해 -페르시아만) 지역에서는 페니키아시대(B.C. 3000년경) 이 전부터 유래된 것으로 알려져 있으며, 후에 중동부 유럽으 로 전파되어 19세기 미생물학의 아버지 파스퇴르(Louis Pasteur 1807-1893)에 의해 발효유의 우수성이 증명되었다 $(20,21)$. 현재까지 발효유의 우수성에 관련된 연구의 진행 상황을 보면 발효유 속 유산균 섭취 시 장내의 부패균과 외부로부터 침입하는 병원성 균의 감염을 예방하고 장내 미생물 균형 유지(22), 발암예방 $(23,24)$, 콜레스테롤 저하 (25), 면역력 증가(26), 혈당 저하 등 여러 기능이 있다고 보고된다(27). 경제의 고속 성장으로 생존방식의 식생활 패턴에서 식품의 다양성과 고급화로 변화하면서 트렌드에 발 맞춰 여러 기능성 식품들이 개발되고 있는 추세이다. 이러한 트렌드에 맞춰 가장 활발히 연구되고 있는 분야가 probiotics 유산균 분리와 발효유 접목 분야이며(28), 기능성 발효유 개발 다양화를 위해 스피루리나(29), 오가피(30) 및 대추(31) 등과 같은 기능성 소재들이 첨가되면서 한층 더 발전된 발효유의 개발을 위해 활발히 연구가 진행되고 있 다.

따라서 본 연구는 신규 식품 소재로써 갈색거저리의 다 양한 영양원 및 기능성 등의 사실에 주목하고 개발된 갈색 거저리 유래 밀리터리 동충하초를 발효유의 영양성 및 기능 성 다양화의 필요성과 접목하여 발효유 신제품을 개발하기 위해 갈색거저리 유래 동충하초의 추출물 선정 및 추출물 첨가량에 따른 발효유를 제조하고 제품의 품질특성과 생리 활성을 확인하였으며, 관능평가를 실시하였다.

\section{재료 및 방법}

재료 및 원유

본 실험에 사용된 갈색거저리 동충하초는 중국 산동성농 업과학원 자원 및 환경연구소에서 구입하여 이물질을 제거 하고 분쇄하여 $-50^{\circ} \mathrm{C}$ 에서 보관하면서 시료로 사용하였다. 우유는 시중에서 서울우유 1 급A를 구입하여 사용하였다. 갈색거저리 동충하초는 Fig. 1과 같다.

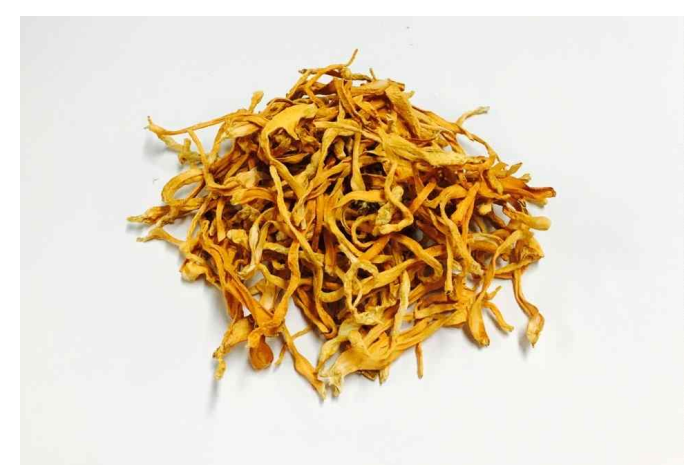

Fig. 1. Photographs of Cordyceps militaris grown upon Tenebrio molitor.

시약 및 배지

사용 용매인 ethanol(HPLC용), acetonitrile(HPLC용) 및 methanol(HPLC용)은 J. T. Baker사(Phillipsburg, NJ, USA) 사용하였고, DPPH용액 및 potassium persulfate는 SigmaAldrich사(St. Louis, MO, USA), Folin-Ciocalteu reagent는 Millipore사(Darmstadt, Germany) 것을 구입하여 사용하였 고, $\mathrm{BCP}$ 배지는 Eiken chemical사(Tokyo, Japan) 것을 구입 하여 사용하였다.

\section{갈색거저리 동충하초 용매별 추출물 제조}

건조된 동충하초 분말 $10 \mathrm{~g}$ 에 증류수와 ethanol 농도를 $30 \%, 50 \%, 70 \%$ 및 $100 \%$ 로 각각 조정한 용매 $1 \mathrm{~L}$ 씩을 넣고 
$80^{\circ} \mathrm{C}$ 에서 30 분간 열수환류추출한 후 추출액을 여과 (Whatman No.2) 하였다. 추출여액은 rotary vacuum evaporator(Büchi RE 121, switzerland)로 $50^{\circ} \mathrm{C}$ 수옥상에서 감압 농축 후 증류수 $200 \mathrm{~mL}$ 로 정용하여 발효유에 사용하 였다.

발효유 제조

원유에 $5 \%$ 설탕과 갈색거저리 동충하초 추출물을 $0.5 \%$, $1.0 \%, 3.0 \%, 5.0 \%, 8.0 \%$ 첨가한 후, $90^{\circ} \mathrm{C}$ 에서 10 분간 살균하 고 냉각하였다. 상업 유산균 starter(FD-DVS YOFLEX MILD $1.050 \mathrm{U}) 0.03 \%$ 를 접종하고 $40^{\circ} \mathrm{C}$ 에서 배양하면서 품질 변화를 확인하였다. 갈색거저리 동충하초 추출물이 첨가된 발효유 제조공정은 Fig. 2와 같다.
Soxhlet 추출법으로 측정하였다.

\section{무기성분 분석}

발효유의 무기성분은 건식분해법(33)으로 전처리하여 분석 하였다. 시료 $0.5 \mathrm{~mL}$ 를 칭량하여 $550-600^{\circ} \mathrm{C}$ 로 회화 시킨 후 증류수 $1 \mathrm{~mL}$ 와 질산 $0.5 \mathrm{~mL}$ 를 가하여 heating plate 에서 백연현상이 일어날 때 까지 가열 시킨 다음 질산 0.5 $\mathrm{mL}$ 를 가한 후 증류수 $100 \mathrm{~mL}$ 로 정용하여 검액으로 하였다. 각 무기성분의 정량은 원자흡광비색계(Perkin Elmer Analyst 300, Perkin Elmer Co., Norwalk, CT, USA)로 각 원소의 표준용액 농도를 1,3 및 $5 \mathrm{ppm}$ 으로 조제하여 표준검 량 곡선을 작성하여 분석하였다.

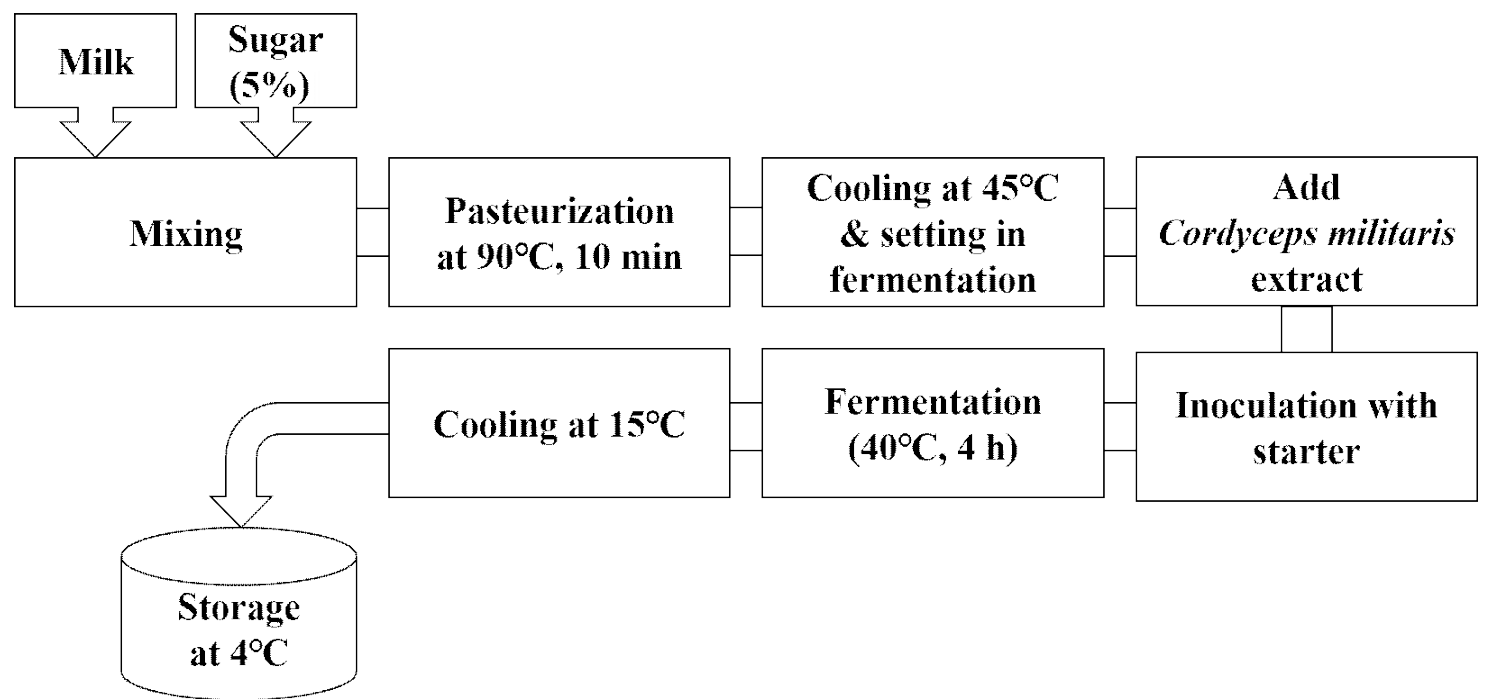

Fig. 2. Procedures for the manufacture methods of fermented milk containing water extracts of Cordyceps militaris grown upon Tenebrio molitor.

\section{발효유 제조과정 중 품질 변화 측정}

갈색 거저리 동충하초 추출물 첨가 발효유의 제조 과정 중 $\mathrm{pH}$ 는 $\mathrm{pH}$ meter(ATI ORION 940, Boston, MA, USA)로 측정하였고, 적정산도는 발효유 $1 \mathrm{~g}$ 에 증류수 $9 \mathrm{~mL}$ 를 가한 후 잘 혼합해 페놀프탈레인용액 3방울을 넣고 $0.1 \mathrm{~N} \mathrm{NaOH}$ 로 중화하여 젖산계수로 환산하였다. 유산균수의 변화는 시료 $1 \mathrm{~mL}$ 채취하여 멸균수에 십진 희석하여 유산균 배지 $\mathrm{BCP}$ 에 접종한 후 Standard Plate Count법으로 $37^{\circ} \mathrm{C}$ 에서 48 시간 배양 후 형성된 colony 수를 측정하여 시료 $1 \mathrm{~mL}$ 중의 $\mathrm{CFU}$ (colony forming unit)를 $\log$ 값으로 나타냈다.

\section{일반성분 분석}

갈색 거저리 동충하초 분말과 열수 추출물 첨가량에 따 른 발효유의 일반성분 분석은 $\mathrm{AOAC}$ 표준분석법(32)에 따 라 실시하였다. 수분은 $105^{\circ} \mathrm{C}$ 상압가열건조법, 회분은 55 $0^{\circ} \mathrm{C}$ 회화처리, 조단백질의 함량은 Kjeldahl법, 조지방은
색도 측정

발효유를 일정량 취해 색도계(super color sp-80, Tokyo, Denshoku, JAPAN)를 이용해 $\mathrm{X}=80.84, \mathrm{Y}=82.22, \mathrm{Z}=92.98$ 인 표준 백색판(standard white plate)으로 보정하여 사용하였 다. 측정값은 명도를 나타내는 L 값(lightness), 적색을 나타 내는 $\mathrm{a}$ 값(redness) 및 황색을 나타내는 $\mathrm{b}$ 값(yellowness)으로 나타내었다.

\section{유리 아미노산 분석}

발효유 아미노산 분석은 Ohara와 Ariyosh의 방법(34)으 로 분석하였다. 시료 $10 \mathrm{~g}$ 에 증류수를 혼합하여 $100 \mathrm{~mL}$ 로 정용한 다음, 원심분리하여 상징액 $10 \mathrm{~mL}$ 를 취해 sulfosalicylic acid $25 \mathrm{mg}$ 을 가하고 $4^{\circ} \mathrm{C}$ 에서 4 시간 동안 방치 후 원심분리 하였다. 그 상징액을 $0.45 \mu \mathrm{M}$ membrane filter로 여과한 여액을 아미노산 자동분석기(Biochrom30+ Amino Acid Analyzer, Cambridge, UK)를 이용해 분석하였다. 
1,1-diphenyl-2-picryhydrazyl(DPPH) 자유 라디칼 소거 활성 측정

$\mathrm{DPPH}$ 자유 라디칼 소거활성은 Blois의 방법(35)의 방법 에 따라 시료의 1.1-diphenyl-2-picryl-hydrazyl(DPPH)에 대 한 수소공여 효과로 측정하였다. 일정 농도의 시료 $2 \mathrm{~mL}$ 에 $2 \times 10^{-4} \mathrm{M} \mathrm{DPPH}$ 용액(dissolved in $99 \%$ methanol)을 $1 \mathrm{~mL}$ 첨가하고, vortex mixing하여 $37^{\circ} \mathrm{C}$ 에서 30 분간 반응시켰다. 이 반응액을 흡수분광광도계를 사용하여 $528 \mathrm{~nm}$ 에서 흡광 도를 측정 하였다. 전자공여능(electron donating ability, $\mathrm{EDA}(\%)$ 으로 측정하였으며, 3회 반복 실험하여 얻은 결과 를 평균과 표준편차로 나타내었다.

2-2'-azino-bis3-ethylbenzothiazoline-6-sulph onic acid(ABTS) 자유 라디칼 소거 활성 측정

$\mathrm{ABTS}$ 자유 라디칼 소거활성은 과황산칼륨(potassium persulfate)의 반응에 의해 생성된 ABTS radical이 시료내의 항산화 물질에 의해 제거되면서 청록색으로 탈색되는 것을 이용한 방법(36)이다. $2.4 \mathrm{mM}$ potassium persulfate 용액을 $7 \mathrm{mM} \mathrm{ABTS}$ 가 되도록 용해시킨 다음 암소에서 24시간 동안 반응 시켰다. ABTS solution을 형성 시킨 후 $734 \mathrm{~nm}$ 에 서 흡광도 값이 $0.70 \pm 0.02$ 가 되게 증류수로 희석하였다. 희석된 용액과 각 추출물을 1:1로 혼합 한 후 $734 \mathrm{~nm}$ 에서 흡광도를 측정하였다.

\section{관능평가}

관능평가는 순천대학교 생명윤리심의위원회 심의 결과 승인을 받은 후 시행되었다(승인번호: 1040173-201706-HR -014-02). 관능검사는 panel 10명을 대상으로 하여 색(color), 맛(taste), 향(flavor)을 평가항목으로 하고 최종적으로 전체 적인 기호도(overall preference)를 7단계 평가법으로 실시 하였다. 채점기준은 아주 좋음; 7점, 보통; 4점, 아주 싫음; 1 점으로 하여 처리구별 유의성 검정을 실시하였다.

발효유의 저장 기간에 따른 품질 특성

갈색거저리 동충하초 열수 환류추출물 첨가 발효유의 저장 기간에 따른 품질특성을 측정하기 위하여 발효 종료 이후의 발효유를 $4{ }^{\circ} \mathrm{C}$ 에서 15 일간 저장하며 3 일 간격으로 총산도, $\mathrm{pH}$, 유산균수를 측정 하여 발효유의 품질특성을 측정하였다. 총산도, $\mathrm{pH}$, 유산균수 측정은 위의 발효유 제 조과정 중 품질변화 측정 실험 방법과 동일하다.

\section{통계분석}

실험결과는 3회 반복 측정하여 SPSS program을 사용하 였고, mean $\pm \mathrm{SD}$ 을 구하였으며 Duncan's multiple range test 로 시료간의 유의차를 다중 비교법으로 분석하였다.

\section{결과 및 고찰}

갈색거저리 동충하초의 일반성분

갈색거저리 동충하초의 일반성분 함량을 측정한 결과는 Table 1 과 같다. 측정 결과 수분 $10.85 \%$, 조단백질 $18.44 \%$, 조지방 $2.07 \%$, 조회분 $5.46 \%$ 의 함량을 보였다. Cho 등(17) 은 누에 동충하초 분말의 일반성분을 측정한 결과 수분, 조단백질, 조지방 및 조회분 함량이 각각 $7.40 \%, 55.77 \%$, $7.11 \%$ 및 $5.39 \%$ 의 함량이었다고 보고하여 조단백질 함량 과 조지방의 함량이 큰 차이를 보였다. 이러한 차이는 동충 하초를 배양시키는 숙주가 본 연구에서는 갈색거저리이고, Cho 등(17)의 연구에서는 누에를 사용하였다는 점에서 숙 주의 영양분 차이에 의해 나타난 결과로 판단된다.

Table 1. Proximate composition of Cordyceps militaris grown upon Tenebrio molitor

$(\%)$

\begin{tabular}{cc}
\hline Composition & $\mathrm{TC}^{1)}$ \\
\hline Moisture & $10.85 \pm 0.33^{2)}$ \\
Crude protein & $18.44 \pm 0.23$ \\
Crude fat & $2.07 \pm 0.05$ \\
Crude ash & $5.46 \pm 0.33$ \\
\hline
\end{tabular}

${ }^{1)}$ Sample: Cordyceps militaris grown upon Tenebrio molitor.

${ }^{2)}$ All values are mean $\pm \mathrm{SD}$.

추출 용매별 DPPH 자유 라디칼 소거 활성

갈색거저리 동충하초의 용매별 추출물의 $\mathrm{DPPH}$ 자유 라 디칼 소거 활성을 측정한 결과는 Fig. 3 과 같다. 용매는 물과 주정 농도 $30 \%, 50 \%, 70 \%, 100 \%$ 로 열수 환류추출

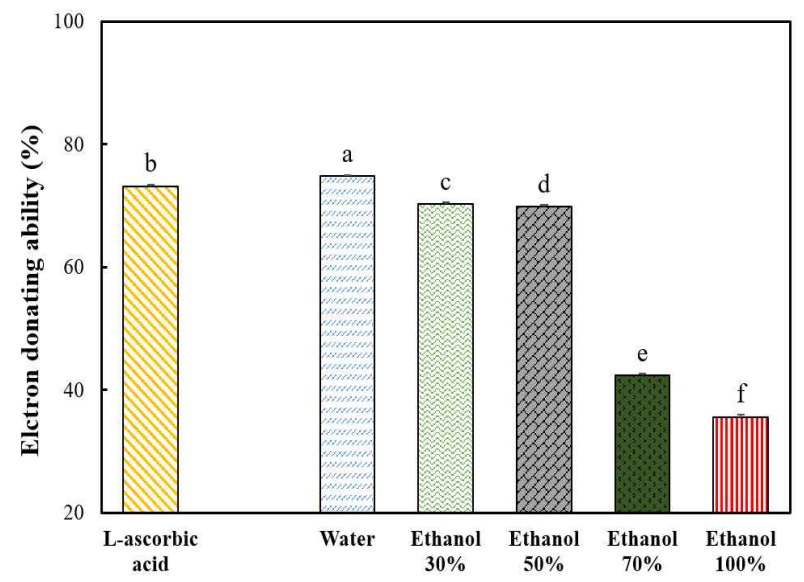

Fig. 3. Electron donating ability of Cordyceps militaris extracts by different solvent.

L-ascorbic acid (10 ppm).

All values are mean \pm SD.

Means in the same column followed by different uppercase letters are significantly different $(\mathrm{p}<0.05, a>b>c>d>e>f)$. 
하였으며 이중 열수 추출물이 $74.81 \mathrm{EDA}($ electron donating ability)\%로 가장 높은 활성을 보였다. 주정 추출물의 경우 ethanol $30 \%$ 농도에서 $70.31 \mathrm{EDA} \%$ 활성을 보였고 농도가 증가할수록 활성이 낮아졌다. 천연 소재에는 다양한 기능 성을 함유하고 있으며, 기능성 성분을 추출하기 위해 여러 추출용매를 사용하게 된다(37). 하지만 식품에서는 직접 섭취를 통해 기능성 성분의 효능을 볼 수 있기 때문에 물과 주정으로 제한을 하고 있다(38). 또한 산업화 측면에서 주정 을 사용할 경우 원가 상승으로 인해 사업성이 떨어지는 문제점이 있다. 따라서 위의 갈색거저리 동충하초 항산화 활성을 측정한 결과 물 추출물에서 가장 높게 나와 식품으 로써의 활용 가치가 충분하며, 본 연구의 발효유 제조에도 열수 추출물을 사용하였다.

\section{발효유 제조과정 중 품질 특성}

갈색 거저리 동충하초 열수 추출물 첨가 발효유의 발효 시간에 따른 산도의 변화는 Fig. $4 \mathrm{~A}$ 와 같다. 발효 중 품질특 성을 평가하기 위하여 발효유 제조 직후 $40^{\circ} \mathrm{C}$ 에서 4 시간 동안 1 시간 간격으로 산도를 측정하였다. 모든 시료구의 초기 산도는 0.21-0.26으로 나타났고 4시간 동안 발효가 진행됨에 따라 산도가 점차 증가하여 정상적인 발효가 진행 됨을 확인 할 수 있었다. 발효가 완료되는 시점인 발효 4시 간째 시료구별 산도 측정 결과를 보면 대조구와 동충하초 추출물 $0.5 \%, 1 \%$ 가 첨가된 시료구는 $0.65-0.67 \%$ 로 비슷한 값을 보였고, 동충하초 추출물 첨가 $3 \%, 5 \%, 8 \%$ 의 시료구 는 $0.73-0.78 \%$ 로 유의적인 차이를 보였다. 이러한 결과는
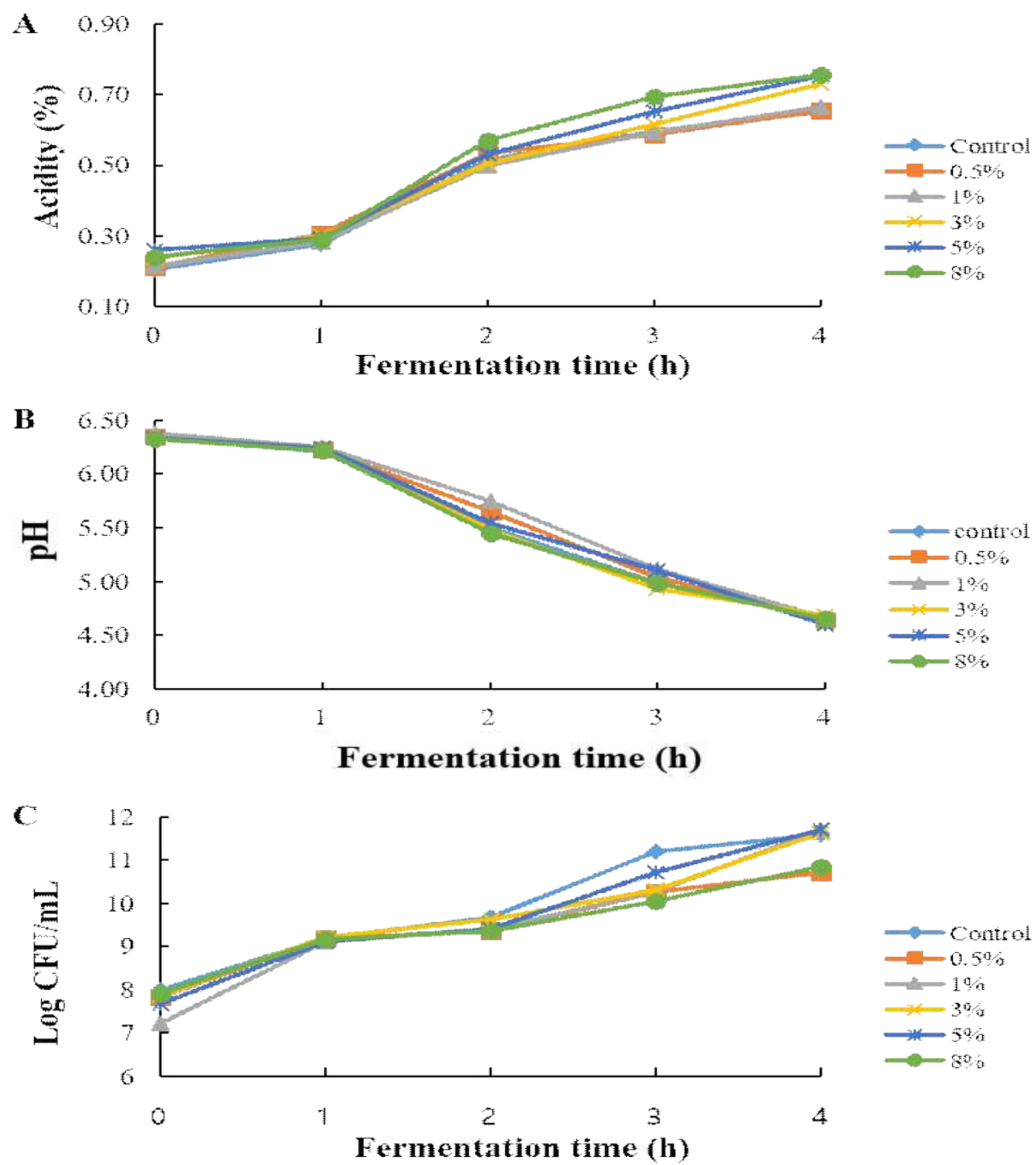

Fig. 4. Changes in the quality according to fermentation time of fermented milk containing water extracts of Cordyceps militaris grown upon Tenebrio molitor.

A, titratable acidity; B, pH; C, viable cell counts. 
눈꽃 동충하초를 첨가한 발효유의 산도 측정 결과 동충하초 의 첨가량이 증가할수록 산도가 증가 하였다는 연구 보고와 유사한 경향을 나타내었다(39). $\mathrm{pH}$ 의 변화를 측정한 결과 는 Fig. 4B에서 보는 바와 같이 초기 $\mathrm{pH}$ 는 6.32-6.38로 나타 내었고 발효가 진행됨에 따라 발효유의 $\mathrm{pH}$ 는 감소되는 경 향을 보였는데 제조 직후에서 발효 1 시간까지의 $\mathrm{pH}$ 변화는 6.38-6.21로 큰 변화가 없었으나 발효 1-2시간 이후부터 큰 폭으로 낮아지는 것을 확인하였다. 발효 4시간째 모든 시료 구의 $\mathrm{pH}$ 는 발효유 제조시 일반적으로 완료 지점으로 설정 되는 4.60-4.66에 도달 하였고, 시료구별 유의적인 차이는 보이지 않았다. 따라서 본 연구에서 설정된 갈색 거저리 열수 추출물 0.5-8.0\% 첨가량은 발효유의 발효에 영향을 미치지 않은 것으로 확인되었다. 갈색거저리 동충하초를 첨가한 발효유의 유산균수 측정 결과는 Fig. $4 \mathrm{C}$ 와 같다. 발효 직후부터 발효 완료시점인 $\mathrm{pH}$ 4.60-4.66까지 도달하 는 시간동안 유산균수는 유의적으로 증가하였다. 모든 시 료군의 유산균수는 발효 직후 7.68-7.94 $\log \mathrm{CFU} / \mathrm{mL}$ 에서 시작하여 발효 1시간은 9.10-9.25 $\log \mathrm{CFU} / \mathrm{mL}$ 로 빠르게 증가하는 양상을 보이다가 발효 종료 시점에서는 모든 시료 군이 10.63-11.70 $\log \mathrm{CFU} / \mathrm{mL}$ 의 균수를 보였다. 시료구별 유산균수는 동충하초 $1 \%$ 첨가 발효유가 $11.70 \log \mathrm{CFU} / \mathrm{mL}$ 으로 가장 높았고, 동충하초 $0.5 \%$ 첨가 발효유가 $10.63 \log$ $\mathrm{CFU} / \mathrm{mL}$ 로 가장 낮았다. 하지만 식품공전상 우리나라의 액상 발효유의 총 유산균수 기준치인 $10^{7} \mathrm{CFU} / \mathrm{mL}$ 이상으 로 규정되어 있다(40). 본 연구에서의 갈색거저리 동충하초 를 첨가한 발효유는 모두 식품공전의 유산균수 기준치에 $10^{2} \mathrm{CFU} / \mathrm{mL}$ 정도를 초과 하여 모든 시료구가 제품으로서 우수한 평가를 받을 수 있을 것으로 판단된다.

\section{일반성분}

갈색거저리 동충하초 열수 추출물의 첨가량에 따른 발효 유의 일반성분 함량 분석 결과는 Table 2 와 같다. 갈색거저 리 동충하초 열수 추출물 첨가량에 따른 수분함량은 대조구 인 갈색 거저리 동충하초를 첨가하지 않은 발효유가 $84.49 \%$ 의 함량을 보였고, 동충하초 $3 \%$ 와 $5 \%$ 를 첨가한 발 효유의 경우 $86.48 \%$ 와 $85.46 \%$ 로 대조구에 비해 약간 높게 나타났으나 유의적인 차이를 보이지 않았다. 조지방 함량 은 $1 \%$ 첨가 시료에서 $4.06 \%$ 로 가장 높았으며 $5 \%$ 시료구가 $3.56 \%$ 로 상대적으로 낮았으나 유의적 차이는 확인되지 않 았다. 조단백질, 조지방, 조회분 함량 또한 갈색 거저리 첨가 량에 따른 유의적인 차이를 보이지 않았다. 국가표준식품 성분표(국립농업과학원)(41)에서 제시된 액상발효유의 수 분은 $83.2 \%$, 단백질 $1.5 \%$, 지방 $0.1 \%$ 회분 $0.3 \%$ 로 본 연구의 결과와 비교해 수분은 비슷한 값을 보였고, 조단백질과 조 지방 함량은 높게 나타났으며, 조회분 함량은 낮은 함량을 보였다.
Table 2. Proximate composition in fermented milk containing water extracts of Cordyceps militaris grown upon Tenebrio molitor

\begin{tabular}{ccccc}
\hline Samples & Moisture & Crude protein & Crude fat & Crude ash \\
\hline Control & $\left.84.49 \pm 0.12^{1 \mathrm{la} 2}\right)$ & $2.78 \pm 0.02^{\mathrm{a}}$ & $3.96 \pm 0.10^{\mathrm{a}}$ & $0.06 \pm 0.01^{\mathrm{a}}$ \\
$0.5 \%$ & $84.32 \pm 0.10^{\mathrm{a}}$ & $2.78 \pm 0.4^{\mathrm{a}}$ & $4.02 \pm 0.07^{\mathrm{a}}$ & $0.06 \pm 0.00^{\mathrm{a}}$ \\
$1 \%$ & $84.26 \pm 0.27^{\mathrm{a}}$ & $2.81 \pm 0.12^{\mathrm{a}}$ & $4.06 \pm 0.00^{\mathrm{a}}$ & $0.06 \pm 0.00^{\mathrm{a}}$ \\
$3 \%$ & $86.48 \pm 1.71^{\mathrm{a}}$ & $2.81 \pm 0.05^{\mathrm{a}}$ & $3.81 \pm 0.18^{\mathrm{a}}$ & $0.07 \pm 0.01^{\mathrm{a}}$ \\
$5 \%$ & $85.46 \pm 1.50^{\mathrm{a}}$ & $2.80 \pm 0.03^{\mathrm{a}}$ & $3.56 \pm 1.10^{\mathrm{a}}$ & $0.06 \pm 0.01^{\mathrm{a}}$ \\
$8 \%$ & $84.84 \pm 4.79^{\mathrm{a}}$ & $2.81 \pm 0.16^{\mathrm{a}}$ & $3.86 \pm 0.24^{\mathrm{a}}$ & $0.06 \pm 0.01^{\mathrm{a}}$ \\
\hline
\end{tabular}

${ }^{1)}$ All values are mean $\pm \mathrm{SD}$.

${ }^{2)}$ Means in the same column followed by different uppercase letters are significantly different $(p<0.05, a>b>c)$.

\section{무기성분}

갈색거저리 동충하초 열수 추출물 첨가량에 따른 발효유 의 무기성분을 분석한 결과는 Table 3 과 같다. 무기성분 중 $\mathrm{K}$ 가 3.02-4.35 mg\%로 가장 높은 함량을 보였고, $\mathrm{Na}$ 와 $\mathrm{Ca}$ 가 2.31-3.10 mg\%, 2.23-2.49 mg\%로 검출 되었다. 첨가량 에 따른 무기성분의 함량을 보면 $\mathrm{K}, \mathrm{Na}, \mathrm{Mg}$ 의 성분은 갈색 거저리 첨가량이 증가 할수록 높아지는 경향을 보였고, $\mathrm{Ca}$ 은 첨가량에 따라 낮아지는 경향을 보였다. $\mathrm{K}, \mathrm{Na}, \mathrm{Mg}$ 의 성분의 함량이 높아지는 이유는 갈색거저리 동충하초에 포함된 무기성분이 우유에 포함된 무기성분 보다 높아 나타 난 결과로 판단되며, $\mathrm{Ca}$ 함량이 낮아지는 이유는 우유에 함유된 $\mathrm{Ca}$ 함량이 높으나 갈색 거저리 동충하초 첨가량이 높아질수록 우유의 사용량이 줄어들어 나타난 결과로 판단된다.

색 도

갈색거저리 동충하초 열수 추출물의 첨가량에 따른 각 시료의 색도를 측정한 결과는 Table 4 와 같다. 색의 명도를 나타내는 L 값, 적색도를 나타내는 a 값과 황색도를 나타내 는 b 값 모두 갈색거저리 동충하초 추출물의 농도 의존적 유의적인 차이를 보였다. L 값은 갈색거저리 동충하초가 첨가되지 않은 발효유의 경우 78.24 였고, 갈색거저리 동충 하초 추출물의 농도가 증가 할수록 낮아져 $8 \%$ 가 첨가된 시료구의 경우 76.46 값을 보였다. $\mathrm{a}$ 값과 b 값은 갈색거저리 동충하초 추출물의 첨가량이 증가 할수록 값이 높아졌다. 이러한 결과는 갈색거저리 동충하초의 자실체가 가지고 있는 색에 기인한 결과로 판단되며, 관능평가에서도 시료 구별 차이를 확인 할 수 있었다.

유리 아미노산

갈색거저리 동충하초 열수 추출물 첨가에 따른 유리아미 노산 함량을 분석한 결과는 Table 5 와 같다. 아미노산 중 taurine, glutamic acid, alanine, proline, valine, isoleucine, leucine, phenylalanine 이 다른 성분들에 비해 많은 함량을 
Table 3. Contents of minerals in fermented milk containing water extracts of Cordyceps militaris grown upon Tenebrio molitor

\begin{tabular}{|c|c|c|c|c|c|c|}
\hline & Control & $0.5 \%$ & $1 \%$ & $3 \%$ & $5 \%$ & $8 \%$ \\
\hline $\mathrm{K}$ & $3.02 \pm 0.01^{1)(2)}$ & $3.02 \pm 0.06^{\mathrm{c}}$ & $3.66 \pm 0.08^{b}$ & $3.67 \pm 0.19^{b}$ & $4.00 \pm 0.35^{\mathrm{ab}}$ & $4.35 \pm 0.68^{\mathrm{a}}$ \\
\hline $\mathrm{Na}$ & $2.31 \pm 0.01^{\mathrm{c}}$ & $2.57 \pm 0.05^{\mathrm{bc}}$ & $2.73 \pm 0.05^{\mathrm{ab}}$ & $2.76 \pm 0.14^{\mathrm{ab}}$ & $2.83 \pm 0.19^{\mathrm{ab}}$ & $3.10 \pm 0.50^{\mathrm{a}}$ \\
\hline $\mathrm{Mg}$ & $0.80 \pm 0.00^{\mathrm{b}}$ & $0.90 \pm 0.00^{\mathrm{ab}}$ & $0.97 \pm 0.06^{\mathrm{ab}}$ & $0.97 \pm 0.06^{\mathrm{ab}}$ & $1.00 \pm 0.10^{\mathrm{a}}$ & $1.00 \pm 0.17^{\mathrm{a}}$ \\
\hline $\mathrm{Ca}$ & $2.49 \pm 0.01^{\mathrm{a}}$ & $2.31 \pm 0.04^{\mathrm{a}}$ & $2.25 \pm 0.06^{\mathrm{a}}$ & $2.44 \pm 0.11^{\mathrm{a}}$ & $2.23 \pm 0.15^{\mathrm{a}}$ & $2.31 \pm 0.37^{\mathrm{a}}$ \\
\hline
\end{tabular}

${ }^{1)}$ All values are mean $\pm \mathrm{SD}$.

${ }^{2}$ Means in the same row followed by different uppercase letters are significantly different $(p<0.05, a>b>c)$.

Table 4. The Hunter's color value of fermented milk containing water extracts of Cordyceps militaris grown upon Tenebrio molitor

\begin{tabular}{cccc}
\hline \multirow{2}{*}{ Sample } & \multicolumn{3}{c}{ Hunter color } \\
\cline { 2 - 4 } & $\mathrm{L}$ & $\mathrm{a}$ & $\mathrm{b}$ \\
\hline Control & $78.24 \pm 0.07^{1 \mathrm{a} 2 \mathrm{a})}$ & $-0.61 \pm 0.05^{\mathrm{ef}}$ & $4.20 \pm 0.13^{\mathrm{f}}$ \\
$0.5 \%$ & $78.10 \pm 0.01^{\mathrm{b}}$ & $-0.55 \pm 0.05^{\mathrm{ef}}$ & $4.94 \pm 0.04^{\mathrm{e}}$ \\
$1 \%$ & $78.00 \pm 0.01^{\mathrm{c}}$ & $-0.42 \pm 0.03^{\mathrm{d}}$ & $6.05 \pm 0.03^{\mathrm{d}}$ \\
$3 \%$ & $77.19 \pm 0.04^{\mathrm{d}}$ & $-0.27 \pm 0.06^{\mathrm{c}}$ & $7.74 \pm 0.03^{\mathrm{c}}$ \\
$5 \%$ & $77.11 \pm 0.02^{\mathrm{e}}$ & $0.24 \pm 0.04^{\mathrm{b}}$ & $10.07 \pm 0.06^{\mathrm{b}}$ \\
$8 \%$ & $76.46 \pm 0.02^{\mathrm{f}}$ & $0.54 \pm 0.03^{\mathrm{a}}$ & $12.13 \pm 0.06^{\mathrm{a}}$ \\
\hline
\end{tabular}

${ }^{1)}$ All values are mean $\pm \mathrm{SD}$.

${ }^{2)}$ Means in the same column followed by different uppercase letters are significantly different $(\mathrm{p}<0.05, \mathrm{a}>\mathrm{b}>\mathrm{c}>\mathrm{d}>\mathrm{e}>\mathrm{f})$.

나타 내었고, 그중에서도 glutamic acid가 가장 높은 함량을 보였다. 열수 추출물 첨가에 따른 glutamic acid의 함량 변화 를 보면 control군에서 $202.19 \mathrm{mg} \%$ 이었고, 농도 의존적으로 증가하여 $8 \%$ 첨가군에서 $571.59 \mathrm{mg} \%$ 함량을 보였다. 전남 농업기술원 곤충잠업연구소에서 보고한 갈색거저리 유리 아미노산 조성을 보면(1) 주요 아미노산으로 proline과 glutamic acid가 주요 아미노산으로 확인되었다고 보고 하 였다. 본 실험에 사용된 동충하초의 경우 갈색거저리를 기 주로 배양된 동충하초이다. 동충하초의 성분 조성은 기주 의 성분 조성에 많은 영향을 받는다. 본 연구에서의 동충하 초 열수 추출물이 첨가된 발효유의 유리 아미노산 측정 결과 주요 아미노산으로 glutamic acid와 proline으로 확인 이 되었고, 첨가량이 증가 할수록 함량 또한 높아지는 결과 를 보여 갈색 거저리 동충하초 첨가 시료에서 기인된 것으 로 판단된다. 그 외에도 alanine성분이 첨가량에 따라 $52.14-98.55 \mathrm{mg} \%$ 로 점차 증가하는 경향을 보였으며 총 유 리 아미노산 또한 control군이 $829.90 \mathrm{mg} \%$ 인 것에 반해 갈색거저리 동충하초 추출물 $0.5,1,3,5,8 \%$ 시료에서는 $1,072.25-1,573.08 \mathrm{mg} \%$ 로 점차 증가하는 것을 확인할 수 있었다.

\section{$\mathrm{DPPH}$ 자유 라디칼 소거 활성}

갈색거저리 동충하초 추출물의 첨가량에 따른 각 시료의
$\mathrm{DPPH}$ 자유 라디칼 소거 활성을 측정한 결과는 Fig. 5 와 같다. DPPH 자유 라디칼 소거 활성은 방향족 아민류 등에 의해 $\mathrm{DPPH}$ 가 환원되어 탈색되는 정도에 따라 항산화 활성 을 측정하는 원리이다(31). 동충하초 추출물의 첨가량에 따른 발효유의 항산화 활성을 알아보기 위하여 시료구의 상등액을 취하여 DPPH 자유 라디칼 소거 활성을 측정하였 다. 대조구와 동충하초 추출물의 첨가량에 따른 $\mathrm{DPPH}$ 자유 라디칼 소거 활성은 갈색거저리 동충하초가 첨가되지 않은 대조구가 $44.39 \%$ 였고, 갈색거저리 동충하초 $0.5 \%, 1 \%$, $3 \%, 5 \%$ 가 첨가된 발효유는 $44.39 \%, 45.83 \%, 46.32 \%$, $46.63 \%, 48.00 \%$ 로 약간 높게 나타났으며, 갈색거저리 동충 하초 $8 \%$ 첨가 발효유는 $58.05 \%$ 로 가장 높게 나타났다. 동충 하초 자실체의 DPPH 자유 라디칼 소거 활성 보고에 따르면 열수 추출물의 DPPH 자유 라디칼 소거 활성이 높게 나타났 으며, 추출물의 첨가량이 증가할수록 $\mathrm{DPPH}$ 자유 라디칼 소거 활성이 높아졌다고 보고하였다(41). 본 연구에서도 열수 추출물에서 활성이 가장 높았으며, 추출물의 첨가량 이 증가할수록 DPPH 자유 라디칼 소거 활성이 높아졌다.

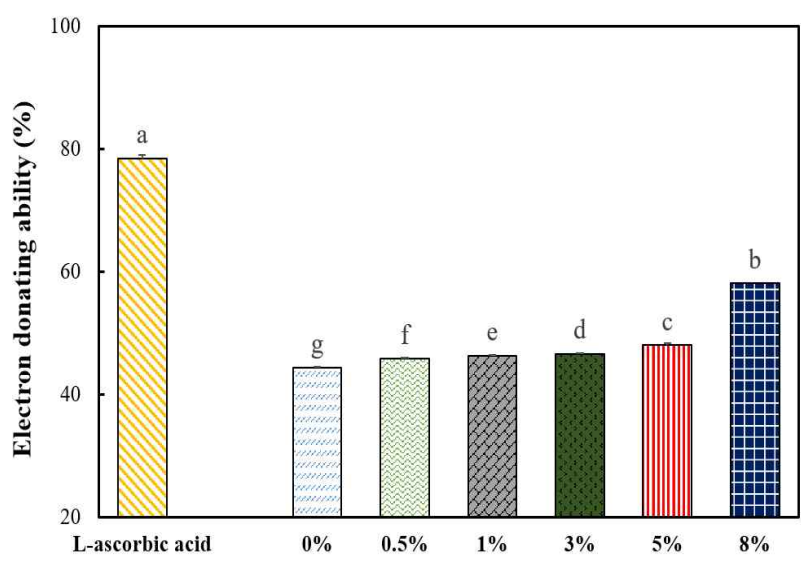

Fig. 5. Electron donating ability of fermented milk containing water extracts of Cordyceps militaris grown upon Tenebrio molitor.

L-ascorbic acid (10 ppm)

All values are mean \pm SD.

Means in the same column followed by different uppercase letters are significantly different $(\mathrm{p}<0.05, \mathrm{a}>\mathrm{b}>\mathrm{c}>\mathrm{d}>\mathrm{e}>\mathrm{f}>\mathrm{g})$. 
Table 5. Free amino acids of fermented milk containing water extracts of Cordyceps militaris grown upon Tenebrio molitor

\begin{tabular}{|c|c|c|c|c|c|c|}
\hline Components & Control & $0.5 \%$ & $1 \%$ & $3 \%$ & $5 \%$ & $8 \%$ \\
\hline Aspartic acid & $1.25 \pm 0.07^{1)(2)}$ & $2.02 \pm 1.75^{\mathrm{c}}$ & $3.74 \pm 0.07^{b}$ & $3.67 \pm 0.12^{b}$ & $37.39 \pm 0.25^{\mathrm{a}}$ & $1.34 \pm 0.24^{c}$ \\
\hline Serine & $30.94 \pm 0.08^{c}$ & $27.93 \pm 0.05^{\mathrm{d}}$ & $1.40 \pm 0.05^{\mathrm{e}}$ & $1.78 \pm 0.78^{\mathrm{e}}$ & $39.32 \pm 0.49^{b}$ & $61.95 \pm 2.01^{\mathrm{a}}$ \\
\hline Taurine & $51.76 \pm 0.77^{\mathrm{f}}$ & $58.12 \pm 0.76^{\mathrm{e}}$ & $67.81 \pm 0.35^{\mathrm{d}}$ & $106.80 \pm 0.84^{\mathrm{a}}$ & $72.19 \pm 0.19^{c}$ & $76.37 \pm 2.05^{\mathrm{b}}$ \\
\hline Glutamic acid & $202.19 \pm 0.32^{\mathrm{f}}$ & $225.26 \pm 2.88^{e}$ & $268.98 \pm 0.94^{\mathrm{d}}$ & $381.65 \pm 0.33^{c}$ & $496.72 \pm 1.27^{b}$ & $571.59 \pm 0.31^{\mathrm{a}}$ \\
\hline Glycine & $4.88 \pm 0.40^{\mathrm{e}}$ & $4.40 \pm 0.46^{\mathrm{e}}$ & $22.90 \pm 0.75^{\mathrm{c}}$ & $18.53 \pm 1.60^{\mathrm{d}}$ & $33.88 \pm 3.78^{\mathrm{a}}$ & $26.37 \pm 1.71^{\mathrm{b}}$ \\
\hline Histidine & $17.88 \pm 0.29^{d}$ & $14.37 \pm 0.23^{\mathrm{e}}$ & $28.07 \pm 1.03^{b}$ & $20.10 \pm 2.82^{\mathrm{cd}}$ & $35.75 \pm 2.25^{\mathrm{a}}$ & $21.48 \pm 0.60^{c}$ \\
\hline Arginine & -3) & $0.65 \pm 0.58^{\mathrm{e}}$ & $3.99 \pm 0.85^{\mathrm{d}}$ & $14.23 \pm 0.87^{\mathrm{c}}$ & $23.36 \pm 2.98^{b}$ & $32.57 \pm 0.87^{\mathrm{a}}$ \\
\hline Threonine & $31.81 \pm 1.22^{\mathrm{bc}}$ & $27.80 \pm 0.71^{\mathrm{cd}}$ & $36.00 \pm 4.15^{\mathrm{a}}$ & $32.41 \pm 1.94^{\mathrm{ab}}$ & $27.02 \pm 2.29^{d}$ & $29.97 \pm 0.21^{\text {bcd }}$ \\
\hline Alanine & $52.14 \pm 1.00^{e}$ & $58.67 \pm 0.66^{\mathrm{d}}$ & $73.49 \pm 3.32^{c}$ & $77.23 \pm 0.15^{\mathrm{b}}$ & $77.96 \pm 0.06^{\mathrm{b}}$ & $98.55 \pm 0.85^{\mathrm{a}}$ \\
\hline Proline & $150.43 \pm 0.59^{e}$ & $162.08 \pm 4.36^{\mathrm{d}}$ & $348.49 \pm 2.62^{b}$ & $359.63 \pm 0.42^{\mathrm{a}}$ & $345.99 \pm 0.90^{b}$ & $336.18 \pm 0.24^{c}$ \\
\hline Tyrosine & $21.46 \pm 0.42^{\mathrm{f}}$ & $74.69 \pm 0.42^{\mathrm{a}}$ & $38.15 \pm 0.17^{\mathrm{c}}$ & $26.28 \pm 0.23^{\mathrm{e}}$ & $44.08 \pm 0.69^{\mathrm{b}}$ & $28.86 \pm 1.44^{\mathrm{d}}$ \\
\hline Cystine & $4.85 \pm 1.42^{\mathrm{e}}$ & $11.69 \pm 0.62^{\mathrm{c}}$ & $3.03 \pm 0.84^{\mathrm{f}}$ & $15.44 \pm 1.18^{\mathrm{b}}$ & $9.99 \pm 0.90^{\mathrm{d}}$ & $19.82 \pm 0.42^{\mathrm{a}}$ \\
\hline Valine & $62.24 \pm 0.34^{\mathrm{e}}$ & $73.80 \pm 0.53^{b}$ & $64.53 \pm 0.43^{\mathrm{d}}$ & $58.61 \pm 0.37^{\mathrm{f}}$ & $77.93 \pm 0.13^{\mathrm{a}}$ & $67.49 \pm 0.34^{c}$ \\
\hline Methionine & $8.42 \pm 0.78^{\mathrm{e}}$ & $59.31 \pm 0.96^{\mathrm{a}}$ & $12.75 \pm 0.55^{\mathrm{d}}$ & $20.17 \pm 1.12^{\mathrm{c}}$ & $19.18 \pm 1.06^{\mathrm{c}}$ & $24.27 \pm 0.97^{\mathrm{b}}$ \\
\hline Lysine & $25.36 \pm 5.77^{\mathrm{b}}$ & $8.19 \pm 0.02^{c}$ & $25.55 \pm 0.24^{b}$ & $9.15 \pm 0.59^{\mathrm{c}}$ & $46.99 \pm 1.55^{\mathrm{a}}$ & $8.24 \pm 1.45^{\mathrm{c}}$ \\
\hline Isoleucine & $41.75 \pm 1.68^{\mathrm{e}}$ & $98.59 \pm 0.68^{\mathrm{a}}$ & $49.09 \pm 0.51^{\mathrm{c}}$ & $44.56 \pm 2.21^{\mathrm{d}}$ & $33.97 \pm 1.10^{f}$ & $58.64 \pm 1.42^{\mathrm{b}}$ \\
\hline Leucine & $61.06 \pm 0.09^{c}$ & $90.00 \pm 0.12^{\mathrm{a}}$ & $75.06 \pm 0.54^{b}$ & $55.17 \pm 1.05^{\mathrm{d}}$ & $51.47 \pm 1.07^{\mathrm{e}}$ & $50.26 \pm 1.07^{e}$ \\
\hline Tryptophane & $5.50 \pm 0.36^{\mathrm{c}}$ & $10.49 \pm 0.41^{b}$ & $11.08 \pm 0.78^{b}$ & $3.08 \pm 0.43^{\mathrm{d}}$ & $20.65 \pm 1.02^{\mathrm{a}}$ & $11.33 \pm 0.69^{b}$ \\
\hline Phenylalanine & $55.98 \pm 0.22^{\mathrm{b}}$ & $64.19 \pm 0.12^{\mathrm{a}}$ & $35.23 \pm 7.06^{\mathrm{d}}$ & $51.81 \pm 0.43^{\mathrm{bc}}$ & $68.35 \pm 1.04^{\mathrm{a}}$ & $47.80 \pm 0.93^{\mathrm{c}}$ \\
\hline $\mathrm{TAA}^{4)}$ & 829.90 & $1,072.25$ & $1,169.34$ & $1,300.30$ & $1,562.19$ & $1,573.08$ \\
\hline$E A A^{5)}$ & 225.01 & 325.59 & 234.65 & 221.25 & 264.60 & 231.12 \\
\hline
\end{tabular}

\footnotetext{
${ }^{1)}$ All values are mean $\pm \mathrm{SD}$.

${ }^{2)}$ Means in the same row followed by different uppercase letters are significantly different $(p<0.05, a>b>c>d>e>f)$.

${ }^{3}$ Not detected.

${ }^{4}$ Total free amino acid.

${ }^{5}$ Essential amino acid (Thr+Val+Met+Ile+Leu+Phe+Lys+Typ)
}

\section{ABTS 자유 라디칼 소거 활성}

2,2'-azino-bis-3-ethylbenzo-thiazoline-6-sulfonic $\operatorname{acid}(\mathrm{ABTS}+)$ 자유 라디칼 소거 활성은 빠른 시간 내 측정이 가능한 항산화 활성을 측정하는 방법 중의 하나로 potassium persulfate와의 반응으로 생성된 ABTS+ 자유 라디칼 소거 활성이 항산화성을 지닌 추출물에 의해 제거되 어 청록색이 탈색되는 것을 이용한 측정법이며, 파장이 734 $\mathrm{nm}$ 로 가시광선 영역에서 벗어나기 때문에 시료의 색에 의 한 간섭의 우려가 적다(42). 갈색 거저리 동충하초 열수 추출물을 첨가한 발효유의 $\mathrm{ABTS}+$ 자유 라디칼 소거 활성 은 Fig. 6 과 같다. 동충하초 추출물이 들어가지 않은 대조구 에서는 $42.60 \%$ 로 가장 낮은 활성을 보였고, 동충하초 추출 물의 첨가량이 증가 할수록 활성이 높아지는 농도에 따른 유의적 차이를 보였으며, 동충하초 추출물 $8 \%$ 를 첨가한 시료구는 $61.93 \%$ 로 가장 높은 활성을 보였다. DPPH 자유 라디칼 소거 활성과 $\mathrm{ABTS}$ 자유 라디칼 소거 활성 측정 결과가 비슷한 경향을 보이는 것으로 보아 동충하초 추출물
이 발효유의 항산화 활성을 높여주는 역할을 하는 것으로 확인되었다.

\section{관능평가}

갈색거저리 동충하초 열수 추출물 첨가량에 따른 발효유 의 관능평가 결과는 Table 6 과 같다. 색의 기호도는 갈색거 저리 동충하초 추출물을 $0.5 \%$ 첨가한 시료구의 기호도가 6.17로 가장 높게 나타났으며 8\%를 첨가한 시료구에서 4.33 으로 가장 낮은 기호도를 보였다. 맛의 기호도 평가는 $1 \%$ 와 $3 \%$ 시료구에서 6.00 으로 동일하게 높은 기호도를 보였으나 향의 기호도에서는 $1 \%$ 가 $5.98,3 \%$ 가 6.08 로 동충하초 열수 추출물을 $3 \%$ 첨가한 시료구가 조금 더 높은 기호도를 보였 다. $8 \%$ 첨가 시료구는 맛과 향에서도 동일하게 4.00 으로 낮은 기호도를 보였다. 종합적인 기호도는 $1 \%, 3 \%, 0.5 \%$, control, $5 \%, 8 \%$ 순으로 높았으며 동충하초 열수 추출물 첨가량이 고농도구 보다 저농도구나 중간농도구에서 색, 맛, 향, 종합적인 기호도 모든 부분이 높은 선호도를 보였다. 
이는 동충하초의 고유의 떪은 맛과 노란색소로 인해 고농도 구로 갈수록 색, 맛, 향, 종합적인 기호도가 낮아지는 것으로 사료된다. 본 연구에서 개발하고자 하는 갈색거저리 동충 하초 열수 추출물 첨가 발효유의 항산화 활성을 높이기 위해서는 갈색거저리 동충하초 열수 추출물을 $8 \%$ 이상 첨 가하여 제조 하는게 좋은 방법이나 발효유의 관능 평가 부분도 고려해야 하기 때문에 기호도를 확보하면서 항산화 활성을 높일수 있는 추가적인 연구가 필요할 것으로 판단된 다.

Table 6. Sensory evaluation of fermented milk containing water extracts of Cordyceps militaris grown upon Tenebrio molitor

\begin{tabular}{ccccc}
\hline \multirow{2}{*}{ Samples } & \multicolumn{4}{c}{ Sensory evaluation } \\
\cline { 2 - 5 } & color & taste & flavor & overall preference \\
\hline Control & $5.75 \pm 1.42^{1 \mathrm{ab} 2)}$ & $5.33 \pm 1.44^{\mathrm{ab}}$ & $5.25 \pm 1.14^{\mathrm{ab}}$ & $5.33 \pm 1.44^{\mathrm{ab}}$ \\
$0.5 \%$ & $6.17 \pm 0.72^{\mathrm{a}}$ & $5.58 \pm 0.90^{\mathrm{ab}}$ & $5.58 \pm 1.00^{\mathrm{ab}}$ & $5.58 \pm 1.00^{\mathrm{a}}$ \\
$1 \%$ & $6.00 \pm 0.74^{\mathrm{a}}$ & $6.00 \pm 1.13^{\mathrm{a}}$ & $5.92 \pm 0.90^{\mathrm{a}}$ & $6.25 \pm 0.87^{\mathrm{a}}$ \\
$3 \%$ & $5.08 \pm 1.00^{\mathrm{bc}}$ & $6.00 \pm 0.74^{\mathrm{a}}$ & $6.08 \pm 0.67^{\mathrm{a}}$ & $6.17 \pm 0.72^{\mathrm{a}}$ \\
$5 \%$ & $4.83 \pm 0.94^{\mathrm{c}}$ & $4.58 \pm 1.62^{\mathrm{bc}}$ & $4.58 \pm 1.62^{\mathrm{bc}}$ & $4.58 \pm 1.00^{\mathrm{bc}}$ \\
$8 \%$ & $4.33 \pm 1.07^{\mathrm{c}}$ & $4.00 \pm 1.76^{\mathrm{c}}$ & $4.00 \pm 1.54^{\mathrm{c}}$ & $4.08 \pm 1.51^{\mathrm{c}}$ \\
\hline
\end{tabular}

${ }^{1)}$ All values are mean $\pm \mathrm{SD}$

${ }^{2)}$ Means in the same column followed by different uppercase letters are significantly different $(p<0.05, a>b>c)$.

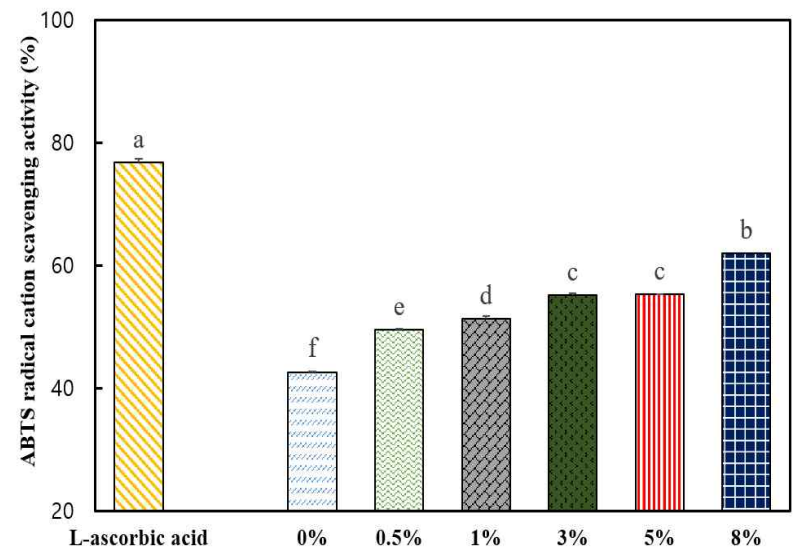

Fig. 6. ABTS radical scavenging activities of fermented milk containing water extracts of Cordyceps militaris grown upon Tenebrio molitor.

L-ascorbic acid (10 ppm).

All values are mean \pm SD.

Means in the same column followed by different uppercase letters are significantly different $(p<0.05, a>b>c>d>e>f)$.

\section{발효유의 저장기간 중 품질 변화 특성}

갈색거저리 동충하초 열수추출물을 첨가한 발효유의 저 장기간에 따른 산도, $\mathrm{pH}$ 및 유산균수 변화를 측정한 결과는 Fig. 7과 같다. 저장기간 중 품질특성을 평가하기 위하여 발효 종료 직후 $4^{\circ} \mathrm{C}$ 에서 15 일 동안 3 일 간격으로 산도를
측정하였다. 모든 시료구의 초기 산도는 $0.65-0.78 \%$ 로 함량 을 보였고, 저장기간 15 일에는 모든 시료구가 유의적 변화 가 없는 $0.72-0.79 \%$ 로 나타났다(Fig. $7 \mathrm{~A}$ ). $\mathrm{pH}$ 의 변화를 측정 한 결과는 Fig. 7B에서 보는 바와 같이 1 일차에서 4.60-4.69 로 나타났고 저장기간에 따라 발효유의 $\mathrm{pH}$ 는 약간 감소되 는 경향을 보였는데 1 일에서 15 일까지 control군이 $4.66 \rightarrow$ 4.45 , 갈색거저리 동충하초 열수추출물 $0.5 \%, 1 \%, 3 \%, 5 \%$ 및 $8 \%$ 첨가 발효유는 각각 $4.64 \rightarrow 4.37,4.66 \rightarrow 4.32,4.69 \rightarrow$ $4.31,4,60 \rightarrow 4.25,4,65 \rightarrow 4.31$ 로 저장기간에 따라 점차 감소 하는 경향을 보였다. 하지만 15 일 이후의 측정된 $\mathrm{pH}$ 값은 식품공전(40)상 액상 발효유의 품질규격에 적합한 결과이 다. 발효유의 저장기간 동안 유산균수 측정 결과는 Fig. $7 \mathrm{C}$ 와 같다. 발효 완료시점의 모든 시료구는 10.93-11.70 $\log \mathrm{CFU} / \mathrm{mL}$ 의 균수를 보였고 저장 9일차에서 9.35-10.65 $\log \mathrm{CFU} / \mathrm{mL}$ 로 약간 감소하는 양상을 보였으며, 저장 15 일 시점에서는 모든 시료군이 9.29-9.46 $\log \mathrm{CFU} / \mathrm{mL}$ 의 균수를 보였다. 저장 1 일에서 15 일 까지 유산균수는 유의적으로 감소하였으나 식품공전(40)에서 고시한 액상 발효유의 총 유산균수 기준치인 $10^{7} \mathrm{CFU} / \mathrm{mL}$ 이상에 충족하는 것으로 나타났다. 이러한 결과를 볼때 갈색거저리 동충하초의 열 수 추출물을 첨가한 발효유는 저장기간 15 일까지 액상 발 효유 품질 규격의 산도, $\mathrm{pH}$ 및 유산균수의 기준치에 적합한 것을 확인하였다.

\section{요 약}

본 연구는 갈색거저리 동충하초 열수 추출물을 첨가한 발효유의 물리화학적 특성과 항산화 효과에 대해 조사하였 다. 갈색거저리 동충하초의 일반성분은 수분 $10.85 \%$, 조단 백질 $18.44 \%$, 조지방 $2.07 \%$, 조회분 $5.46 \%$ 로 나타났으며 용매별 DPPH 자유 라디칼 소거 활성을 측정한 결과 물 추출물이 $74.81 \mathrm{EDA} \%$ 로 가장 높은 활성을 보였다. 갈색 거저리 동충하초 열수 추출물 첨가 발효유의 발효시간에 따른 산도는 동충하초 추출물의 첨가량이 증가할수록 산도 가 증가 하였다. $\mathrm{pH}$ 는 발효 4시간째 4.60-4.66에 도달 하였 고, 시료구별 유의적인 차이는 보이지 않았다. 유산균수는 동충하초 $1 \%$ 첨가 발효유가 $11.70 \log \mathrm{CFU} / \mathrm{mL}$ 으로 가장 높았고, 동충하초 $0.5 \%$ 첨가 발효유가 $10.63 \log \mathrm{CFU} / \mathrm{mL}$ 로 가장 낮았다. 동충하초 열수 추출물 첨가량에 따른 발효유 의 수분함량은 유의적인 차이를 보이지 않았다. 조단백질 의 함량과 조지방 및 조회분 함량 또한 갈색 거저리 첨가량 에 따른 유의적인 차이를 보이지 않았다. 발효유의 무기성 분 중 $\mathrm{K}$ 가 $3.02-4.35 \mathrm{mg} \%$ 로 가장 높은 함량을 보였고, $\mathrm{Na}$ 와 $\mathrm{Ca}$ 가 2.31-3.10 mg\%와 2.23-2.49 mg\%로 검출 되었다. 발효 유의 색도를 측정한 결과 $\mathrm{L}$ 값은 갈색거저리 동충하초 열수 추출물의 농도가 증가 할수록 낮아졌고, $\mathrm{a}$ 값과 $\mathrm{b}$ 값은 갈색 

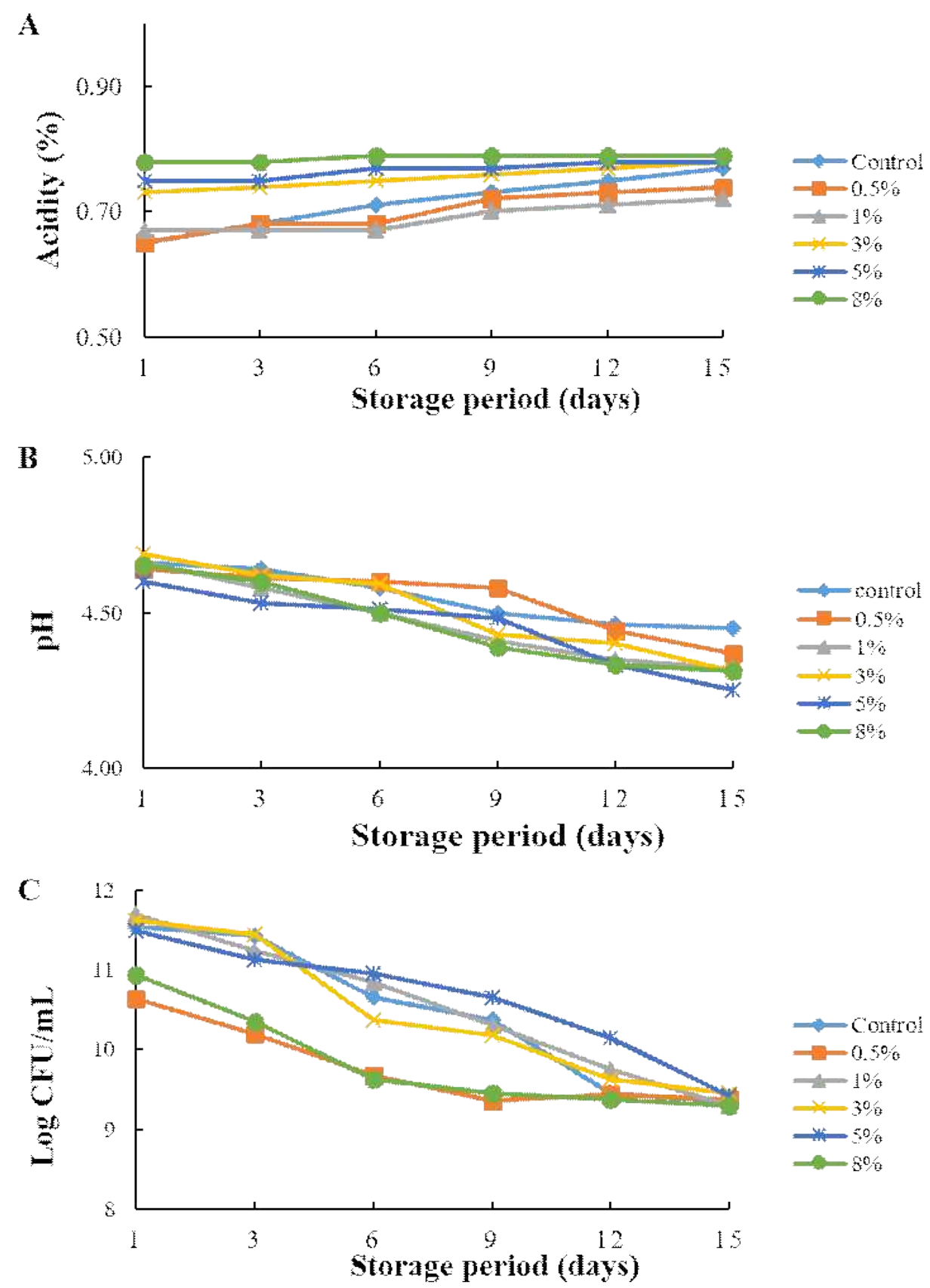

Fig. 7. Changes in the quality according to storage period of fermented milk containing water extracts of Cordyceps militaris grown upon Tenebrio molitor.

A, titratable acidity; $\mathrm{B}, \mathrm{pH} ; \mathrm{C}$, viable cell counts.

거저리 동충하초 추출물의 첨가량이 증가 할수록 값이 높아 졌다. 발효유의 유리아미노산은 control군이 $829.90 \mathrm{mg} \%$ 인 것에 반해 갈색거저리 동충하초 추출물 $0.5,1,3,5,8 \%$ 시료에서는 $1,072.25-1,573.08 \mathrm{mg} \%$ 로 추출물의 첨가량이 증가 할수록 높은 함량을 보였다. 발효유의 DPPH 자유라디 칼 소거능을 측정한 결과 갈색거저리 동충하초 열수 추출물 $8 \%$ 첨가 발효유가 $58.05 \%$ 로 가장 높게 나타났다. ABTS 자유라디칼 소거능은 동충하초 열수 추출물이 들어가지
않은 대조구에서는 $42.60 \%$ 로 가장 낮은 활성을 보였고, 동충하초 추출물의 첨가량이 증가 할수록 활성이 높아지는 농도에 따른 유의적 차이를 보였다. 갈색거저리 동충하초 열수 추출물을 첨가한 발효유의 관능평가 결과 종합적인 기호도는 $1 \%, 3 \%, 0.5 \%$, control, $5 \%, 8 \%$ 순으로 높았다. 갈색거저리 동충하초 열수 추출물을 첨가한 발효유의 저장 기간에 따른 산도, $\mathrm{pH}$ 및 유산균수 변화를 측정한 결과 발효유는 저장기간 15 일까지 액상 발효유 품질 규격의 산 
도, $\mathrm{pH}$ 및 유산균수의 기준치에 적합하였다.

\section{References}

1. Jeonnam Agricultural Reserch \& Extension Services (2015) Development of feed additives for poultry with insects. Rural Development Administration, Naju, Korea, p 61-67

2. Ramos-Elorduy J, Pino MJM (1990) Caloric content of some edible insects of mexico. Reviews of Society Qim Mexico, 34, 56-68

3. Ramos-Morales JA, Rojas-Guadalupe M, Shapiro-Ilan DI, Tedders WL (2007) Tenebrio molitor as a source of insect protein. USDA, 1-21

4. Moreki JC, Tiroesele B, Chiripasi SC (2012) Prospects of utilizing insects as alternative sources of protein in poultry diets in botswana: a review. J Anim Sci Adv, 2, 649-658

5. Lee HW, Jeong MJ, Mun MJ (1999) Morphological characteristics of superposition ommatidium in the mealworm beetle, Tenebrio molitor. Korean J Entomol, 29, 85-93

6. Lee JH, Kim NK, Lee DY, Lee CH (1999) Protective effect of selected amino acids and food extracts on ethanol toxicity decrement in rat liver. Korean J Food Sci Technol, 31, 802-808

7. Park YK, Choi YC, Lee YB, Lee SH, Lee JS, Kang SH (2012) Fecundity, life span, developmental periods and pupal weight of Tenebrio molitor L. (Coleoptera: Tenebrionidae). J Seric Entomol Sci, 50, 126-132

8. Ravzanaadii N, Kim SH, Choi WH, Hong SJ, Kim NJ (2012) Nutritional value of mealworm, Tenebrio molitor as food source. Int J Ind Entomol, 25, 93-98

9. Yoo JM, Hwang JS, Goo TW, Yun EY (2013) Comparative analysis of nutritional and harmful components in Korean and Chinese mealwarms (Tenebrio molitor). J Korean Soc Food Sci Nutr, 42, 249-254

10. Vinokurov KS, Elpidina EN, Oppert B, Prabhakar S, Zhuzhikov DP, Dunaevsky YE, Belozersky MA (2006) Diversity of digestive proteinases in Tenebrio molitor (Coleoptera:Tenebrionidae) larvae. 145, 126-137

11. Jo SY (2000) Healthy longevity silkworm Cordyceps. Shinil Corporation, Seoul Korea, p 3-11

12. Sung JM (1996) Korea Cordyceps. Kyohaksa, Seoul Korea, p 10-15

13. Kim AJ, Yuh CS, Bang IS (2007) A qualitative investigation of Dongchunghacho jelly with assorted increments of paecilomyces japonica powder. Korean J Food Nutr, 20, 40-46

14. Jo SY (2000) Effectiveness and utilization of silkworm Cordyceps. National Nutr, 4, 20

15. Han DS, Song HN, Kim SH (1999) Cordyceps: New functional food material. Food Science and Industry, 32, 56-63

16. Park DG (2006) The quality properties of loaf bread with Cordyceps militaris powder. MS Thesis, Sunchon University, Korea, p 3-4

17. Cho HC (2008) A study on the quality characteristics of paecilomyces japonica powder added Seolgiddeok MS Thesis, Chungwoon University, Korea, p 1-5

18. Park WH (2009) Quality properties of herbal vinegar using medicinal herbs fermented with Cordyceps militaris. MS Thesis, Sunchon University, Korea, p 1-4

19. MAFRA (2017) Processed food market report: yogurt. Ministry of Agriculture, Food and Rural Aff, Sejong, Korea, p 2-3

20. Kosikowski FV (1978) Cheese and fermented milk foods. Brooktondal, New York, NY, USA, p 443-448

21. Metchnikoff E (1977) The prolongation of life. Arno Press, New York, USA, p 69

22. Shah NP (1999) Probiotic bacteria antimicrobial and antimutagenic properties. Probiotica, 6, 1-3

23. Yoon H, Benamouzig R, Little J, Francois-Collange M, Tome D (2000) Systematic review of epidemiological studies on meat, dairy products, and egg consumption and risk of colorectal adenomas. Eur J Cancer Prev, 9, 151-164

24. Bang BH, Park HH (2000) Preparation of yogurt added with green tea and mugwort tea and quality characteristics. J Korean Soc Food Sci, 29, 854-859

25. Klaver FAM, Meer RVD (1993) The assumed assimilation of cholesterol by lactobacilli and Bifidobacterium bifidum is due to their bile saltdeconjugating activity. Appl Env Microbiol, 59, 1120-1124

26. Marteau P, Vaerman JP, Dehennin JP, Bord JP, Brassart D, Pochart P, Desjeux JF, Rambaud JC (1997) Effects of intrajejunal perfusion and chronic ingestion of Lactobacillus johnsonii strain La1 on serum concentrations and jejunal secretions of immunoglobulins and serum proteins in healthy humans. Gastroenterol Clin Biol, 21, 293-298

27. Cho YH, Shin HJ, Chang CH, Nam MS (2006) Studies 
on the development of the yogurt decreasing blood glucose. Korean J Food Sci Anim Resour, 26, 257-262

28. Min KA (2012) Study of exopolysaccharide producing lactic acid bacteria isolated from kimchi for a probiotic yogurt starter. MS Thesis, Sejong University, Korea, $p$ 13-15

29. Shin YM (2007) Quality characteristics and functionality of spirulina added yoghurt. MS Thesis, Chungnam University, Korea, p 6-7

30. Oh HS (2016) Quality characteristics and antioxidant activity of yogurt added with acanthopanax powder. MS Thesis, Seoul University, Korea, p 3-4

31. Kim AN (2012) Quality characteristics of yogurt added jujube hot-water extracts. MS Thesis, Daegu Haany University, Korea, p 2-3

32. AOAC (1995) Official methods of analysis $16^{\text {th }} \mathrm{ed}$. Association of official analytical chemists, Washington DC, USA, $p$ 7-10

33. KFDA (2007) Test method in general. Int'l Food code (separate volume), Korea food and drug administration, Cheongju, Korea

34. Ohara I, Ariyoshi S (1979) Comparison of protein precipitants for the determination of free amino acid in plasma. Agr Biol Chem, 43, 1473-1478

35. Abe N, Nemoto A, Tsuchiya Y, Hojo H, Hirota A (2000) Studies on the 1.1-diphenyl-2-picrylhydrazyl radical scavenging mechanism for a 2-pyrone compound. Biosci Biotech Bioch, 64, 306-333
36. Re R, Pellegrini N, Proteggente A, Pannala A, Yang M, Rice-Evans C (1999) Antioxidant activity applying an improved ABTS radical cation decolorization assay. Free Radical Biol Med, 26, 1231-1237

37. Dong S (2004) Physiological activities of clove by the different extraction solvents. MS Thesis, Hankyong University, Korea, p 1-4

38. Ko WH, Hong JK, Lee SW, Cha JU, Baek HH, Park HJ (2012) The effects of coating treatments on enteric coating of the soft capsules containing omega- 3 fatty acids. Korean J Food Sci Technol, 44, 168-172

39. Bae SH (2008) Preparation and quality evaluation of fermented milk by using the extracts of paecilomyces japonica. MS Thesis, Yeungnam University, Korea, $p$ 15-21

40. KFDA (1999) Official book of food. Korea food and drug administration, Cheongju, Korea, p 169

41. National Institute of Agricultural Sciences (2011) National standard food ingredients table. Rural Development Administration, Wanju, Korea, p 53-60

42. Ban HJ (2011) Effect of polygonaceae extract on sulfofication and SD-rat scalp damage after oxidation hairdye. MS Thesis, Wonkwang University, Korea, $\mathrm{p}$ 34-35 